\title{
Discrimination of Different Body Structure Indexes of Elite Athletes in Combat Sports Measured by Multi Frequency Bioimpedance Method
}

\author{
Discriminación de Diferentes Índices de Estructura Corporal de Atletas de Elite en \\ Deportes de Combate Medidos por el Método de Bioimpedancia de Múltiples Frecuencias
}

Milivoj Dopsaj'; Milan Markovic'; Goran Kasum²; Srecko Jovanovic ${ }^{3}$; Nenad Koropanovski ${ }^{4}$; Marko Vukovic ${ }^{5}$ \& Milos Mudric ${ }^{6}$

DOPSAJ, M.; MARKOVIC, M.; KASUM, G.; JOVANOVIC, S.; KOROPANOVSKI, N.; VUKOVIC, M. \& MUDRIC, M. Discrimination of different body structure indexes of elite athletes in combat sports measured by multi frequency bioimpedance method. Int. J. Morphol., 35(1):199-207, 2017.

SUMMARY: In order to achieve high results in sports, it is necessary to provide an adequate status of an athlete in according to various factors, among which the body structure is one of greater importance. The aim of this research is to define the most discriminated indicators of body structure indexes, thanks to which a specific change of physical structure can be observed according to a branch of sport and type of combat sport. Variables in the research were: body height, body mass, body mass index, free fat mass index, fat mass index, protein mass index, skeletal muscle mass index, percent of body fat, percent of skeletal muscle mass and protein fat index. The measuring of the body composition is realized by using multichannel segmental bioimpedance with InBody 720 apparatus, applied on the total of 112 male high level senior-age athlete members of different national team's member of Republic of Serbia (62 judokas, 29 Greco-Roman style wrestlers and 21 karatekas). The discriminative analysis has shown that subsamples of the athletes statistically differ in morphology on Wilks' lambda level $(0.435, \mathrm{p}=0.000)$, and that following variables have the highest discrimination compared to athlete respondents in sport function: percent of skeletal mass (0.34), percent of body fat $(0.28)$ and protein fat index $(0.26)$, as the first isolated factor $(\mathrm{p}=0.000)$ by which is explained $86.3 \%$, that is body weight $(0.74)$, skeletal muscle index $(0.73)$, protein mass index $(0.72)$, body mass index $(0.72)$ and free fat mass index $(0.70)$, as the second factor $(\mathrm{p}=0.030)$ by which $13.7 \%$ variability of measured body structure space is explained. By establishing body structure models of judokas, wrestlers and karatekas for variables examined and by using modern technological method of measuring (InBody 720, 2008) we got new information that characterize specificity of the sport, which all contribute to spreading and improving already existing knowledge in the sports sciences and sport body morphology area.

KEY WORDS: Combat sports; Elite athletes; Body structure; Bioimpedance.

\section{INTRODUCTION}

Organization of modern elite sport as a controlled system is based on multi annual practice. During this process, the athlete goes through various stages of basic and sports specific training, but also through the various stages of psychological, social, biological, morphological and competitive development. Constant control over the effects of the applied training facilities and methods must be used continuously during training, and it has essential importance for progress control and development of athlete`s competitive mastership (Issurin, 2008). As an athlete progresses in the relation to different elements of sport development i.e. sport mastership, raises professional need as well as practical possiblities for more specific studies of each element of athelete's system, especially training effect individually (Sánchez-Puccini et al., 2014).

The main aim in sport is to achieve the best possible competitive result, that is why the training is used (technical,

\footnotetext{
${ }^{1}$ Department of Analysis and diagnosis in sport, Faculty of Sport and Physical Education, University of Belgrade, Blagoja Parovica 156 Str, 11030 Belgrade, Serbia. ${ }^{2}$ Department of Combat sports - Wrestling, Faculty of Sport and Physical Education, University of Belgrade, Blagoja Parovica 156 Str, 11030 Belgrade, Serbia. ${ }^{3}$ Department of Combat sports - Karate, Faculty of Sport and Physical Education, University of Belgrade, Blagoja Parovica 156 Str, 11030 Belgrade, Serbia. ${ }^{4}$ Department of Special physical education - Karate, Criminalistic - Police Academy, Cara Dusana 196 Str., 11080 Zemun, Serbia.

${ }^{5}$ Department of Combat sports - Judo, Faculty of Sport and Physical Education, University of Belgrade, Blagoja Parovica 156 Str, 11030 Belgrade, Serbia.

${ }^{6}$ Department of Combat sports - Karate, Faculty of Sport and Physical Education, University of Belgrade, Blagoja Parovica 156 Str, 11030 Belgrade, Serbia.
} 
tactical, physical, psychological and etc.) as a meaning to fulfill the same. For gaining top sports results sever factors should be completed. Among them very important part is training system and morphological factor (Dopsaj et al., 2013). Body structure is of great importance in a sport where its importance plays a main role due to sports`achievements, still in certain groups of sports it is a limited performing factor related to technical propositions defined by weight categories (wrestling, boxing, judo, karate, rowing, etc).

Most experts and scientists engaged in the athlete`s morphology believe that there is a relationship between some sport characteristics and an athletes morphological characteristics. In fact in most cases, young athletes choose a sport which is appropriate to their morphology, as morphology of their bodies provide them advantage. On the other side, by training chosen sport, and considering adjustment phenomena over certain sports` specificity, an athlete gains morphological characteristics typical for a certain sport. It is shown that top sports achievements are more often associated with body structure of an athlete (Cirkovic et al., 2010; Kim, et al., 2011). Therefore, in most sports significant focus is aimed to studying body structure status of and an active athlete and to those who consider getting engaged into some sport (Sánchez-Puccini et al.).

Group of combat sports, the object of this study consists of three most popular combats sports in Republic of Serbia, and those are: judo, Greco-Roman wrestling and karate (Cirkovic et al.). The first two belongs to Olympics group of sports (judo and wrestling) and all three are characteristic for sporting competitors by weight categories, specific for each sport.

Judo consists of 7 weight categories. For men those are: $-60 \mathrm{~kg},-66 \mathrm{~kg},-73 \mathrm{~kg},-81 \mathrm{~kg},-90 \mathrm{~kg},-100 \mathrm{~kg} \mathrm{i}+100 \mathrm{~kg}$. Greco-Roman wrestling has characteristic match where the grips can be used performed from the waist to the top and it is consisted of the categories 59, 66, 71, 75, 80, 85, 98 i 130kg (71 i 80kg are not Olympics categories). While karate consists of only 5 weight categories which are: $-60,-67,-75,-84$ and $+84 \mathrm{~kg}$.

A large number of morphological and body structure parameters to should be observed and analyzed may significantly affect the choice of techniques that are most commonly used in a fight (Kasum \& Dopsaj, 2012). Firstly this is related to the longitudinal and transverse of the skeleton dimensions and diameter of joints, which are largely determined by inherited factors. The impact of specific multi annual training on some morphological parameters can be significant, but some may not significantly affect the planning. This is the case with the bone system, where under the influence of training stress, receives a high specific bone volume and density (Cirkovic et al.). Somatotype of elite male combat sports athletes are characterized by distinct mesomorphic characteristics (muscularity, low fat level), while women have a strong endomorphic characteristics that are often adjoin the mesomorphic. Ideal, judokas, wrestler, karate fighter should have a body fat level of 7-10\% built by optimal combination of training and adequate nutrition, with the exception of the top weight categories (Kasum \& Dopsaj).

In combat sports control of body weight is one of the key issues during the training and competition. It is no surprise that athletes must take accelerated process of extenuation, which can cause negative health effects or negative competitive efficiency i.e. performance (Cirkovic et al.). That is why technological efficiency of sports training system is to be upgraded, even in relation to control processes of fighter body status by enhancement mechanisms of applied scientific methods by which athlete's body status is controlled and managed toward optimum desirable structure (SterkowiczPrzybycien', 2010; Kasum \& Dopsaj). Therefore the studies in the field of defining innovative indicators of body structure one of the essential factor for updating knowledge of fighter's body structure characteristics.

In the last few years bioelectrical impedance analysis is widely used in medical and sport practice and more and more present's standard method for determination of complete body structure and body segments. Measuring procedure is simple and doesn't take much time, method is noninvasive, relatively cheap, applicable for measuring large groups and can be applied regardless of age or sex (Gibson et al. 2008; Sillanpää et al. 2014).

Object of this research is analysis body composition characteristics of elite sport competitors in martial arts/combat sports - judo, Greco-roman wrestling and karate. Aim of this research is to define the most discriminative indicator of body structure indexes, by tracking body morphology change related to sports branch and kind of combat sport. All findings obtained in this research will be generally used due to sports training technologies, and in the terms of redefining morphological characteristics present models for examined fighters, as well as updating systems of sport nutrition effects and methodological control procedures of fighter's body structure.

\section{MATERIAL AND METHOD}

In relation to the basic method, this study according to its character belongs to a scientific research category. In relation to form of research this study has characteristics of 
fundamental and applied research, as it provides innovation of existing general knowledge in the area of elite athletes body structure, which can be used in combat sports. Basic method of finding in this study will be inductive conclusion as based on individual indicators of body structure will be explained procedures and processes in different examined combat sports.

Subjects. This research included 112 participants, male elite athletes, members of different Serbian national teams. Sample consists of high level athletes competitors in two Olympics sports, judo (N=62) and Greco-Roman wrestling $(\mathrm{N}=29)$ and one non Olympics sport, karate $(\mathrm{N}=21)$. Basic characteristics of total sample were: age $-23.26 \pm 3.85 \mathrm{yrs}$, training experience - $13.30 \pm 4.23$ yrs., body mass $83.29 \pm 13.63 \mathrm{~kg}$, body height $-180.78 \pm 8.76 \mathrm{~cm}, \mathrm{BMI}-$ $25.37 \pm 2.80 \mathrm{~kg} \cdot \mathrm{m}^{-2}$ While the values for individual sports:

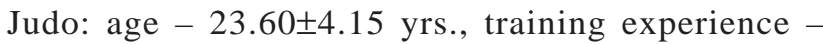
$13.13 \pm 4.79$ yrs., body mass $-86.15 \pm 14.29 \mathrm{~kg}$, body height - $183.00 \pm 8.72 \mathrm{~cm}, \mathrm{BMI}-25.60 \pm 2.80 \mathrm{~kg} \cdot \mathrm{m}^{-2}$, Wrestling: - age- 23.56 \pm 3.27 yrs., training experience $-12.65 \pm 3.13$ yrs., body mass - 82.08 $13.10 \mathrm{~kg}$, body height $175.68 \pm 8.58 \mathrm{~cm}, \mathrm{BMI}-26.44 \pm 2.34 \mathrm{~kg} \cdot \mathrm{m}^{-2}$, Karate: age $-21.81 \pm 3.43$ yrs., training experience $-14.62 \pm 3.88$ yrs., body mass $-76.49 \pm 9.55 \mathrm{~kg}$, body height $-181.3 \pm 6.10$ $\mathrm{cm}, \mathrm{BMI}-23.23 \pm 2.26 \mathrm{~kg} \cdot \mathrm{m}^{-2}$.

All examinees were informed about testing conditions and procedure and voluntarily participated in this research. Complete process of tracking this sample was carried out during the period 2011-2014. in scientific research laboratory in Faculty of Sport and Physical Education, University of Belgrade. The research was carried out in accordance with the conditions of Declaration of Helsinki: Recommendations Guiding Physicians in Biomedical Research Involving Human Subjects (http:// www.cirp.org/library/ethics/ helsinki/), and with the approval and consent of the Ethics Committee of the Faculty of Sport and Physical Education, University of Belgrade.

Testing. Testing procedure of measuring body constitution was carried out by usage of bioelectrical impedance analysis (BIA), precisely InBody 720 Tetapolar 8 points by tactical electrodes system (Biospace Co, Ltd). Inbody 720 device (720 Inbody Biospace 2008) used the latest technology of measuring body structure by method DSMBIA (Direct Segmental Multi frequency Bioelectrical Impedance Analysis). Bioelectrical impedance Inbody 720 showed high test - retest, reliability and accuracy (ICC 0.9995) (Gibson et al.). This kind of equipment is intensively used in sports health clinics and other health care improvement institutions.
All participants were measured in accordance with manufacturer's suggestions. And prior to testing they got these instructions:

- Measuring was taken in the morning between 8:00 and 10:00am,

- Participants were asked to abstain from large meal after 9 am day before testing.

- Participants were asked to abstain from eating and drinking prior to testing on the measuring day,

- Participants were asked to refrain from extreme physical exertions 24 hours prior to measuring, and last training should have been performed at least 12 hours prior to measuring,

- Participants were asked to abstain from consuming any alcohol drinks 48 hours before measuring,

- Participants were asked to urinate and defecate at least 30 minutes prior to measuring,

- Participants were in the standing position at least 5 minutes prior to measuring due to normal fluid distribution in the body,

- Measuring was taken in the standing position, as it was suggested by manufacturer (hands aside placed $15 \mathrm{~cm}$ laterally from the body).

Variables. This study comprised 10 variables, 2 of which were primary and 8 were derived (index) variables, defining the morphology and composition of the body. The latter variables were:

1. $\mathrm{BH}$ - body height, expressed in $\mathrm{cm}$;

2. BM - body mass, expressed in $\mathrm{kg}$;

3. BMI - body mass index, expressed in $\mathrm{kg} \cdot \mathrm{m}^{-2}$;

4. FFMI - free fat mass index, calculated as: FFM (free fat mass, in $\mathrm{kg}$ ) $\cdot \mathrm{BH}^{2}$ (body height, in $\mathrm{m}$ ), expressed in $\mathrm{kg} \mathrm{FFM} \cdot \mathrm{m}^{-2}$;

5. FMI - fat mass index, calculated as: FM (fat mass, in $\mathrm{kg}$ ) · $\mathrm{BH}^{2}$ (body height, in $\mathrm{m}$ ), expressed in $\mathrm{kg}$ Fat mass $\cdot \mathrm{m}^{-2}$;

6. PMI - protein mass index, calculated as: PM (protein mass, in $\mathrm{kg}$ ) $\cdot \mathrm{BH}^{2}$ (body height, in $\mathrm{m}$ ), expressed in $\mathrm{kg}$ Protein $^{\mathrm{m}-2}$;

7. SMMI - skeletal muscle mass index, calculated as: SMM (skeletal muscle mass, in $\mathrm{kg}$ ) $\cdot \mathrm{BH}^{2}$ (body height, in $\mathrm{m}$ ), expressed in $\mathrm{kg}$ Muscle $\cdot \mathrm{m}^{-2}$;

8. $\mathrm{PBF}$ - percent of body fat, calculated as: $\mathrm{BF}$ (body fat, in $\mathrm{kg}$ ) / BM (body mass, in $\mathrm{kg}$ ), expressed in \%;

9. PSMM - percent of skeletal muscle mass, calculated as: SMM (skeletal muscle mass, in kg) / BM (body mass, in $\mathrm{kg}$ ), expressed in \%;

10. PFI - protein fat index, calculated as relation between proteins (in $\mathrm{kg}$ ) and body fat mass (in $\mathrm{kg}$ ), expressed in $\mathrm{kg}$.

Statistics. All raw results are, in the first step of statistical 
analysis, submitted to calculation of basic descriptive statistics by measures of central tendency (MEAN), measure of statistical dispersion (SD, cV\%, Std. Error absolutely and relatively, lower and higher $95 \%$ confidence interval bound). Regularity of variables distribution is tested by KolmogorovSmirnov nonparametric test. To determine differences between of participants subsamples MANOVA is used in general meaning, while ANOVA is used in partial meaning. Difference between pairs of individual variables of examined subsamples is tested by Bonferroni criterion. To define the most important factor of morphological variables difference in function of subsamples we used Discriminative analysis. All statistical analysis were accomplished by statistical softwares SPSS 19.0, while the level of statistical significance is defined by $95 \%$ and the probability values of a p <0.05 (Hair et al., 1998).

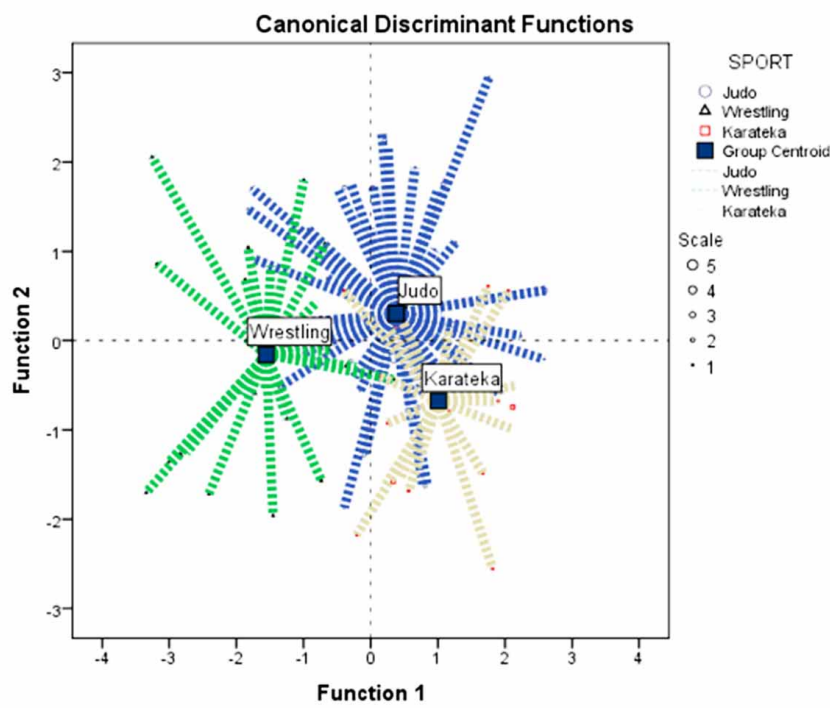

Fig 1. Centroid positions of athletes in relation to a martial arts sport and examined body structure index

\section{RESULTS}

In Tables I and II all descriptive indicators of tested morphological index are shown in the relation to total sample of participants, as well as a single martial arts sport. Table III shows results of body structure index differences (MANOVA and ANOVA) with regard to type of analyzed martial arts sport.

The figure 1 shows centroid positions of athletes in relation to a combat sport and tested body structure index. In relation to the first isolated factor (discriminative factor) judokas were allocated on 0.38 , wrestlers -1.55 , a karatekas on 1.01 centroid position, while considering the second factor position for the judokas was $0.30,-0.16$ for wrestlers and 0.67 for karatekas.

Table IV and V display result of discriminative analysis with results of defined canonic discriminant function.

\section{DISCUSSION}

Researches of body structure are very important in the relation to the general population as well as population of different level competitive athletes and different sport branches (Janssen et al., 2000; Andreaoli et al., 2001; Dopsaj et al., 2010; Sillanpää et al.; Sánchez-Puccini et al.). Related to the general population the phenomenon of body structure is studied to research the connection with non-infectious diseases, i.e health status, as well as in relation to the measuring methods and body structure modeling with different races (Wang et al., 1994; Janssen et al.; Sillanpää et al.), while with population of athlete research is aimed at the phenomenon of body structure adaptation on training

Table I. Basic descriptive statistics of whole combat sport subject sample.

\begin{tabular}{|c|c|c|c|c|c|c|c|c|}
\hline \multirow[b]{3}{*}{ V ariables } & \multirow[b]{3}{*}{ MEAN } & \multicolumn{6}{|c|}{ Whole combat sport subjects sample $(\mathrm{N}=112)$} & \multirow{3}{*}{ K-S Z } \\
\hline & & \multirow[b]{2}{*}{ SD } & \multirow[b]{2}{*}{$\mathrm{cV} \%$} & \multirow{2}{*}{$\begin{array}{l}\text { Std. } \\
\text { Error } \\
\text { (Aps) }\end{array}$} & \multirow{2}{*}{$\begin{array}{l}\text { Std. } \\
\text { Error } \\
(\%)\end{array}$} & \multicolumn{2}{|c|}{ Confidence Interval 95} & \\
\hline & & & & & & $\begin{array}{l}\text { Lower } \\
\text { Bound }\end{array}$ & $\begin{array}{l}\text { Higher } \\
\text { Bound }\end{array}$ & \\
\hline$\overline{\mathrm{BH}}(\mathrm{cm})$ & 180.78 & 8.76 & 4.85 & 0.83 & 0.46 & 179.95 & 181.61 & 0.725 \\
\hline $\mathrm{BM}(\mathrm{kg})$ & 83.29 & 13.63 & 16.36 & 1.29 & 1.55 & 79.00 & 81.58 & 0.735 \\
\hline BMI $\left(\mathrm{kg} \cdot \mathrm{m}^{-2}\right)$ & 25.37 & 2.80 & 11.04 & 0.26 & 1.02 & 25.11 & 25.63 & 0.764 \\
\hline FFMI $\left(\mathrm{kg} \cdot \mathrm{m}^{-2}\right)$ & 22.62 & 2.24 & 9.90 & 0.21 & 0.93 & 22.41 & 22.83 & 0.658 \\
\hline FMI $\left(\mathrm{kg} \cdot \mathrm{m}^{-2}\right)$ & 2.74 & 1.22 & 44.53 & 0.12 & 4.38 & 2.62 & 2.86 & 1.145 \\
\hline PMI $\left(\mathrm{kg} \cdot \mathrm{m}^{-2}\right)$ & 4.51 & 0.46 & 10.20 & 0.04 & 0.89 & 4.47 & 4.55 & 0.698 \\
\hline $\mathrm{SMMI}\left(\mathrm{kg} \cdot \mathrm{m}^{-2}\right)$ & 13.00 & 1.39 & 10.69 & 0.13 & 1.00 & 12.87 & 13.13 & 0.655 \\
\hline PBF $(\%)$ & 10.62 & 3.84 & 36.16 & 0.36 & 3.39 & 10.26 & 10.98 & 0.724 \\
\hline PSMM (\%) & 51.31 & 2.34 & 4.56 & 0.22 & 0.43 & 51.09 & 51.53 & 0.722 \\
\hline PFI (kg) & 2.02 & 1.13 & 55.94 & 0.11 & 5.45 & 1.91 & 2.13 & 2.103 \\
\hline
\end{tabular}


DOPSAJ, M.; MARKOVIC, M.; KASUM, G.; JOVANOVIC, S.; KOROPANOVSKI, N.; VUKOVIC, M. \& MUDRIC, M. Discrimination of different body structure indexes of elite athletes in combat sports measured by multi frequency bioimpedance method. Int. J. Morphol., 35(I):199-207, 2017.

Table II. Basic descriptive statistics of combat sport subject subsample.

\begin{tabular}{|c|c|c|c|c|c|c|c|c|}
\hline \multicolumn{9}{|c|}{ Judokas subjects sample $(\mathrm{N}=62)$} \\
\hline Variables & MEAN & SD & $\mathrm{cV} \%$ & $\begin{array}{l}\text { Std. Error } \\
\text { (Aps) }\end{array}$ & $\begin{array}{l}\text { Std. Error } \\
(\%)\end{array}$ & $\begin{array}{c}\text { Confidenc } \\
\text { Lower } \\
\text { Bound }\end{array}$ & $\begin{array}{l}\text { val } 95 \% \\
\text { Higher } \\
\text { Bound }\end{array}$ & $\begin{array}{c}\mathrm{K}-\mathrm{S} \mathrm{Z} \\
\text { (p value) }\end{array}$ \\
\hline $\mathrm{BH}(\mathrm{cm})$ & 183.00 & 8.72 & 4.77 & 1.11 & 0.61 & 181.89 & 184.11 & 0.930 \\
\hline $\mathrm{BM}(\mathrm{kg})$ & 86.15 & 14.29 & 16.59 & 1.82 & 2.11 & 82.82 & 89.49 & 0.671 \\
\hline $\mathrm{BMI}\left(\mathrm{kg} \cdot \mathrm{m}^{-2}\right)$ & 25.60 & 2.80 & 10.94 & 0.36 & 1.41 & 24.94 & 26.25 & 0.765 \\
\hline FFMI $\left(\mathrm{kg} \cdot \mathrm{m}^{-2}\right)$ & 22.62 & 2.01 & 8.89 & 0.26 & 1.15 & 22.13 & 23.11 & 0.857 \\
\hline FMI $\left(\mathrm{kg} \cdot \mathrm{m}^{-2}\right)$ & 2.96 & 1.34 & 45.27 & 0.17 & 5.74 & 2.65 & 3.26 & 1.045 \\
\hline 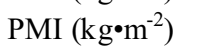 & 4.51 & 0.41 & 9.09 & 0.05 & 1.11 & 4.41 & 4.61 & 0.793 \\
\hline SMMI $\left(\mathrm{kg} \cdot \mathrm{m}^{-2}\right)$ & 13.01 & 1.25 & 9.61 & 0.16 & 1.23 & 12.71 & 13.32 & 0.844 \\
\hline PBF $(\%)$ & 11.32 & 3.96 & 34.98 & 0.50 & 4.42 & 10.39 & 12.26 & 0.673 \\
\hline PSMM (\%) & 50.94 & 2.36 & 4.63 & 0.30 & 0.59 & 50.38 & 51.50 & 0.804 \\
\hline PFI (kg) & 1.83 & 0.96 & 52.46 & 0.12 & 6.56 & 1.55 & 2.11 & 1.477 \\
\hline \multicolumn{9}{|c|}{ Wrestlers subjects sample $(\mathrm{N}=29)$} \\
\hline $\mathrm{BH}(\mathrm{cm})$ & 175.68 & 8.58 & 4.88 & 1.59 & 0.91 & 174.09 & 177.27 & 0.581 \\
\hline $\mathrm{BM}(\mathrm{kg})$ & 82.08 & 13.11 & 15.97 & 2.43 & 2.96 & 77.21 & 86.95 & 0.571 \\
\hline $\mathrm{BMI}\left(\mathrm{kg} \cdot \mathrm{m}^{-2}\right)$ & 26.44 & 2.34 & 8.85 & 0.43 & 1.63 & 25.48 & 27.39 & 0.656 \\
\hline FFMI $\left(\mathrm{kg} \cdot \mathrm{m}^{-2}\right)$ & 24.07 & 2.03 & 8.43 & 0.38 & 1.58 & 23.36 & 24.79 & 0.482 \\
\hline FMI $\left(\mathrm{kg}^{\prime} \mathrm{m}^{-2}\right)$ & 2.36 & 0.98 & 41.53 & 0.18 & 7.63 & 1.92 & 2.80 & 0.543 \\
\hline PMI $\left(\mathrm{kg} \cdot \mathrm{m}^{-2}\right)$ & 4.82 & 0.40 & 8.30 & 0.07 & 1.45 & 4.67 & 4.96 & 0.544 \\
\hline SMMI $\left(\mathrm{kg} \cdot \mathrm{m}^{-2}\right)$ & 13.88 & 1.25 & 9.01 & 0.23 & 1.66 & 13.44 & 14.33 & 0.505 \\
\hline PBF (\%) & 8.84 & 3.22 & 36.43 & 0.60 & 6.79 & 7.47 & 10.21 & 0.662 \\
\hline PSMM (\%) & 52.55 & 2.04 & 3.88 & 0.38 & 0.72 & 51.73 & 53.38 & 0.564 \\
\hline PFI (kg) & 2.51 & 1.43 & 56.97 & 0.26 & 10.36 & 2.10 & 2.91 & 1.542 \\
\hline \multicolumn{9}{|c|}{ Karateka subjects sample $(\mathrm{N}=21)$} \\
\hline $\mathrm{BH}(\mathrm{cm})$ & 181.30 & 6.10 & 3.36 & 1.33 & 0.73 & 179.97 & 182.63 & 0.635 \\
\hline $\mathrm{BM}(\mathrm{kg})$ & 76.49 & 9.55 & 12.49 & 2.08 & 2.72 & 70.77 & 82.22 & 0.539 \\
\hline $\mathrm{BMI}\left(\mathrm{kg} \cdot \mathrm{m}^{-2}\right)$ & 23.23 & 2.26 & 9.73 & 0.49 & 2.11 & 22.10 & 24.35 & 0.516 \\
\hline FFMI $\left(\mathrm{kg} \cdot \mathrm{m}^{-2}\right)$ & 20.62 & 1.58 & 7.66 & 0.35 & 1.70 & 19.77 & 21.46 & 0.515 \\
\hline FMI $\left(\mathrm{kg}^{\prime} \mathrm{m}^{-2}\right)$ & 2.60 & 1.03 & 39.62 & 0.22 & 8.46 & 2.08 & 3.13 & 0.476 \\
\hline PMI $\left(\mathrm{kg} \cdot \mathrm{m}^{-2}\right)$ & 4.09 & 0.32 & 7.82 & 0.07 & 1.71 & 3.93 & 4.27 & 0.478 \\
\hline SMMI $\left(\mathrm{kg} \cdot \mathrm{m}^{-2}\right)$ & 11.75 & 0.97 & 8.26 & 0.21 & 1.79 & 11.23 & 12.27 & 0.611 \\
\hline PBF (\%) & 10.99 & 3.64 & 33.12 & 0.79 & 7.19 & 9.38 & 12.60 & 0 \\
\hline PSMM (\%) & 50.71 & 2.10 & 4.14 & 0.46 & 0.91 & 49.74 & 51,68 & 0.565 \\
\hline PFI (kg) & 1.89 & 0.99 & 52.38 & 0.22 & 11.64 & 1.42 & 2.37 & 1.036 \\
\hline
\end{tabular}

Table III. Results of morphological index differences in relation to type of analyzed combat sport (MANOVA \& ANOVA).

\begin{tabular}{|c|c|c|c|c|c|c|c|}
\hline \multicolumn{8}{|c|}{ Multivariate Tests - MANOVA } \\
\hline & Value & $\mathrm{F}$ & Hypothesis df & Error df & Sig. & $\begin{array}{l}\text { Noncent. } \\
\text { Parameter }\end{array}$ & $\begin{array}{l}\text { Observed } \\
\text { Power }^{c}\end{array}$ \\
\hline Wilks' lambda & 0.435 & $5.78 \mathrm{a}$ & 18.00 & 202.00 & 0.000 & 104.10 & 1.00 \\
\hline \multicolumn{8}{|c|}{ Univariate Tests - ANOVA } \\
\hline Dependent Variable & Sum of Squares & $\mathrm{df}$ & Mean Square & $\mathrm{F}$ & Sig. & $\begin{array}{l}\text { Noncent. } \\
\text { Parameter }\end{array}$ & $\begin{array}{c}\text { Observec } \\
\text { Power }^{\mathrm{a}}\end{array}$ \\
\hline BW & 1521.69 & 2 & 760.85 & 4.34 & 0.02 & 8.69 & 0.74 \\
\hline BMI & 132.76 & 2 & 66.38 & 9.85 & 0.00 & 19.70 & 0.98 \\
\hline FFMI & 145.68 & 2 & 72.84 & 19.25 & 0.00 & 38.50 & 1.00 \\
\hline FMI & 7.51 & 2 & 3.75 & 2.58 & 0.08 & 5.16 & 0.51 \\
\hline PMI & 6.32 & 2 & 3.16 & 20.44 & 0.00 & 40.89 & 1.00 \\
\hline SMMI & 55.35 & 2 & 27.67 & 19.04 & 0.00 & 38.08 & 1.00 \\
\hline PBF & 125.70 & 2 & 62.85 & 4.53 & 0.01 & 9.06 & 0.76 \\
\hline PSMM & 60.77 & 2 & 30.39 & 6.07 & 0.00 & 12.14 & 0.88 \\
\hline PFI & 9.44 & 2 & 4.72 & 3.89 & 0.02 & 7.78 & 0.69 \\
\hline
\end{tabular}


Table IV. Results of discriminative analysis with results of defined canonical functions.

\begin{tabular}{ccccc}
\hline \multicolumn{5}{c}{ Eigenvalues } \\
\hline Function & Eigenvalue & \% of Variance & Cumulative \% & Canonical \\
1 & $0.92^{\mathrm{a}}$ & 86.30 & 86.30 & 0.69 \\
2 & $0.15^{\mathrm{a}}$ & 13.70 & 100.00 & 0.36 \\
a. First 2 canonical discriminant functions & were used in the analysis. \\
\hline \multicolumn{5}{c}{ Wilks' Lambda } \\
\hline Test of Function(s) & Wilks' Lambda & Chi-square & df & Sig. \\
1 through 2 & 0.45 & 83.82 & 14 & 0.000 \\
2 & 0.87 & 14.47 & 6 & 0.030 \\
\hline
\end{tabular}

Table V. Results of defined structure matrix in the most significant difference factor of body structure index.

\begin{tabular}{lcc}
\multicolumn{3}{c}{ Structure Matrix } \\
& \multicolumn{2}{c}{ Function } \\
& 1 & 2 \\
\hline PSMM $^{\mathrm{a}}$ & $-0.34^{*}$ & -0.11 \\
PBF & $0.28^{*}$ & 0.27 \\
PFI & $-0.26^{*}$ & -0.23 \\
BW & -0.02 & $0.74^{*}$ \\
SMMI & -0.54 & $0.73^{*}$ \\
PMI & -0.57 & $0.72^{*}$ \\
BMI & -0.34 & $0.72^{*}$ \\
FFMI & -0.55 & $0.70^{*}$ \\
FMI & 0.16 & $0.40^{*}$ \\
\hline Pooled within-groups correlations \\
between discriminating variables and \\
standardized canonical discriminant \\
functions. Variables ordered by \\
absolute size of correlation within \\
function. \\
*. Largest absolute correlation between \\
each variable and any discriminant \\
function \\
a. This variable not used in the analysis.
\end{tabular}

methods, body mass reduction or on defining the model of the same (Artioli et al., 2010; Vecchio et al., 2011; Kim et al.; Clarys et al., 2011; Kasum \& Dopsaj; Dopsaj et al., 2013).

Related to body height, results showed that average height in judokas was $183.0 \pm 8.7 \mathrm{~cm}, \quad$ karate $181.3 \pm 6.1 \mathrm{~cm}$, wrestlers $175.7 \pm 8.6 \mathrm{~cm}$ (Table II), and statistically significant difference was defined between judokas and wrestlers $(p=0.000)$, i.e. karate and wrestlers ( $\mathrm{p}=$ $0.005)$. When we compare this results with standards of young and healthy people in Republic of Serbia (Dopsaj et al., 2010), it can be asserted that participants from all three martial arts sports belong to a group of average height individuals (178.6 - $184.5 \mathrm{~cm})$, and from aspect of percentile distribution judokas were 63 $\%$, karate fighters $50 \%$ and wrestlers $16 \%$ of population height. (Dopsaj et al., 2010).

When we compared results of this study with foreign studies, it was noted that average height of elite Brazilian judokas is $176.2 \pm 8.9 \mathrm{~cm}$ (Franchini et al., 2007), while average height of Caucasian male judo athletes is $173.5 \pm 6.1 \mathrm{~cm}$ (Andreoli et al., 2001). Related to karate athletes body height from other countries results showed that average height of elite Croatian karate athletes is 178.2 \pm 6.8 (Katic et al., 2005), Polish $179.0 \pm 5.0 \mathrm{~cm}$ (Sterkowicz-Przybycien). Elite Iranian wrestlers average height is $172.9 \pm 9.0 \mathrm{~cm}$ (Mirzaei \& Akbarnezhad, 2008), and Turkish 173.0 \pm 8.8 (Arslanoglu et al., 2015). Obviously participants in this research are taller in comparison with athletes of the same sports but different geographic regions, judokas approximately for $4.67 \%$, karate athletes for $1.51 \%$, and wrestlers $1.59 \%$, i.e. our participants are about $2.59 \%$ taller than athletes from mentioned countries. An explanation can be found in the fact that citizens of Republic of Serbia in relation to body height belong to the group of tall nations, and that the population of Republic of Serbia belongs to the type of genetically Dinaric highlanders (Grasgruber et al., 2014).

By individual comparison of average body mass within analyzed sports we noticed the highest average value with judokas is $86.15 \pm 14.29 \mathrm{~kg}$, then wrestlers $82.08 \pm 13.11 \mathrm{~kg}$, and then karate athletes $76.49 \pm 9.55 \mathrm{~kg}$ (Table II). Results of univariate test showed that body mass (BM) among subsamples are statistically significantly different on level $\mathrm{F}=4.34$ and $\mathrm{p}=0.015$, but between variable pairs $\mathrm{BM}$ is statistically different only between karate athletes and judokas on level $\mathrm{p}=0.014$. Related to standars BM of healthy and young people in Republic of Serbia it can be asserted that wrestlers and karate athletes belong to a group of average BM (74.19 $83.96 \mathrm{~kg}$ ), while judokas has BM above average level (83.97 - $88.82 \mathrm{~kg}$ ). Related to distribution of percentiles judokas are on $80 \%$ (percentile), wrestlers on $65 \%$ and karate athletes on $42 \%$ of population body mass (Dopsaj et al., 2010).

By comparison of combat sports individually with foreigners` results, we noticed that body mass of Brazilian judokas is $90.6 \pm 23.8 \mathrm{~kg}$ (Franchini et al.). Iranian national wrestling team has similar values like encompassed sample of this research $81.5 \pm 20.2 \mathrm{~kg}$ (Mirzaei \& Akbarnezhad), while wrestler of Turkish national team has lower average value BM $77.88 \pm 18.84 \mathrm{~kg}$ (Arslanoglu et al.). In comparison with Croatian karate athletes BM results are slightly lower $75.38 \pm 9.90 \mathrm{~kg}$ (Katic et al.), while research sample of elite Polish karate athletes shows great difference in BM $86.1 \pm 8.25 \mathrm{~kg}$. By comparison of average Caucasian body mass BM $77.0 \pm 11 \mathrm{~kg}$, i.e. Asians race $68.0 \pm 10 \mathrm{~kg}$ (Wang et $a l$.), generally the fact is that by training process an athletes' muscle mass in examined combat sports increases, probably as a result of training and diet. 
Related to examined subsamples we can assert that average BMI value of wrestlers is $26.44 \pm 2.34 \mathrm{~kg} / \mathrm{m}^{2}$, judokas $25.60 \pm 2.80 \mathrm{~kg} / \mathrm{m}^{2}$ and karate athletes $23.23 \pm 2.26$ $\mathrm{kg} / \mathrm{m}^{2}$ (Table II). In comparison with Italian judokas, where in average value of BMI is $24.7 \pm 2.1 \mathrm{~kg} / \mathrm{m}^{2}$ (Andreoli et al.) our sample has $3.64 \%$ higher $\mathrm{kg} / \mathrm{m}^{2}$. By observing values BMI of our wrestlers and Korean wrestlers where average BMI value is from $22.9 \pm 1.8 \mathrm{~kg} / \mathrm{m}^{2}$ (Lee et al., 2009), also we can assert that our sample has even $15.46 \%$ more $\mathrm{kg} / \mathrm{m}^{2}$. However in comparison with BMI values of karate athletes from our sample within elite Polish karate athletes average value of BMI is from $26.8 \pm 2.0 \mathrm{~kg} / \mathrm{m}^{2}$ (SterkowiczPrzybycien), which means that Serbian karate athletes has $15.37 \%$ less $\mathrm{kg} / \mathrm{m}^{2}$.

Related to standards for BMI in population of healthy Serbian persons it can be stated that only karate athletes belongs to a group of people with average BMI (22.76 $25.18 \mathrm{~kg} / \mathrm{m}^{2}$ ), while judokas belongs to a group of above average value BMI $\left(25.19-26.40 \mathrm{~kg} / \mathrm{m}^{2}\right)$, and wrestlers to a group of people with high BMI $\left(26.41-28.82 \mathrm{~kg} / \mathrm{m}^{2}\right)$. Related to distribution of percentiles, wrestlers are on $86 \%$ o (percentile), judokas on $77 \%$, and karate athletes on $40 \%$ o of BMI value of population (Dopsaj et al., 2010).

Average values of the fat and muscle percentage in the body in relation to the entire sample examined athletes in analyzed sports is $10.62 \pm 3.84 \%$ for BF and $51.31 \pm 2.34$ $\%$ for SMM (Table II). By individual combat sports judo athletes had \%BF at the level of $11.32 \pm 3.96 \%$ and $\%$ SMM at the level of $50.94 \pm 2.36$, wrestler's had a $\% \mathrm{BF}$ at $8.84 \pm 3.22$ and $52.55 \pm 2.04$ of $\% \mathrm{SMM}$ and karate athletes had a $\% \mathrm{BF}$ $10.99 \pm 3.64$ and $50.71 \pm 2.10$ of \% SMM. Compared to the healthy and non-trained population of Caucasians and Asians found to have a value of $\% \mathrm{BF}$ of $19.3 \pm 6.4 \%$ and $21.4 \pm 6.3$, respectively (Wang et al.), tested athletes have nearly twice lower percentage of body fat. In relation to standards \%SMM defined by multichannel bioelectrical impedance for adults, health and recreation trained men whose average value is asserted \% SMM at the level of $47.59 \pm 4.34 \%$ (Rakic et al., 2013), the value of \%SMM with the whole test sample of athletes by $8.01 \pm 2.11 \%$ higher (Judo $-7.04 \%$, the wrestlers $-10.42 \%$ and karate athletes $-6.56 \%$ ).

Related to the index variables, among whom were some are newly introduced for martial arts elite athletes, and for more precisely information can be used to define the body structure of combat sports in different weight categories, the highest level for discrimination due to the tested athletes in the function of the sports branches has been established with the following variables: percent of skeletal muscle mass (0.34), percent of body fat $(0.28)$ and protein fat index $(0.26)$, first isolated factor $(p=0.000)$, which explained $86.30 \%$ of variance measurement, and skeletal muscle mass index (0.73), protein mass index (0.72), body mass index (0.72) and fat free mass index $(0.70)$, as a second factor $(\mathrm{p}=0.030)$, which explains the remaining $13.70 \%$ of measurements variance (Table IV)

Considering the fact that martial art sports have characteristic weight categories, athletes strive for the optimal or ideal body composition, where strategy is aimed to favoring muscle compared to fat tissue, because by this way the contractile potential of fighters is increased in relation to the potential manifestations of strength, power and speed, and consequently minimize the presence of fat in the body (Mirzaei \& Akbarnezhad; Kim et al.). Also, defined structure of body structure differences, and set of influence of individual variables in relation to the tested morphological space is given guidelines for tested sports for redefining the morphological model, i.e. form which athletes should aim, through training and proper nutrition. Also, by monitoring the value of the most sensitive body structure index a valid means i.e. tool may be provided for the process of body weight correction in the acute phase and accelerated changes of body category, and in order to prevent the loss of desirable physical element, or sports performances (Artioli et al.; Kasum \& Dopsaj).

\section{CONCLUSION}

For achieving top sport results it is necessary to provide adequate status of an athlete considering several factors. Related to combat sports, where weight categories are determined by rules, morphological space as well as body structure presents one of the most significant factor of success.

Subject of this research is analysis body structure characteristics of elite athletes competitors in combat sports - judo, Greco-roman wrestling and karate, while the aim is defining the most discriminative indicator of body structure, i.e. morphological index by which we can track specific changes of body constitution in relation to a sport branch and type of combat sport. Examined variables present combination of classic (standard) and recently projected index provided by measuring technology with multichannel segmental bioimpedance method (device InBody 720). Examinees sample in research included 112 elite senior athletes, male sex, members of national Serbian teams, consists of 62 judokas, 29 Greco-roman wrestlers and 21 karate athletes.

Discriminative analysis showed that subsamples of 
the athletes were statistically significantly different by body structure on level Wilks' lambde - 0.435, $(\mathrm{p}=0.000)$, that next variables are the most discriminative in relation to tested athletes in the sport function: percent of skeletal muscle mass (0.34), percent of body fat index (0.28), as the first isolated factor $(\mathrm{p}=0.000)$ which explains $86.3 \%$, respectively, and body weight (0.74), skeletal muscle mass index (0.73), protein mass index (0.72), body mass index $(0.72)$, and free fat mass index $(0.70)$, as second factor $(\mathrm{p}=0.030)$ which explains $13.7 \%$ variability of measuring space.

By establishing body structure models of judokas, wrestlers and karate athletes for tested variables and by using latest technological measuring methods (InBody 720) new information are obtained that characterize the sport's specificity, which all contribute to development and improvement of existing knowledge in this area. By tracking given variables, particularly changes in their structure, which all provides the new index value, such as PFI, SMMI, FFMI and FMI may enable accurate control of the system in determining body structure and impact of training type process on the quality of the same.

\section{ACKNOWLEDGEMENTS}

The paper is a part of the project "Effects of the Applied Physical Activity on Locomotor, Metabolic, Psychosocial and Educational Status of the Population of the Republic of Serbia", number III47015, funded by the Ministry of Education, Science and Technological Development of the Republic of Serbia - Scientific Projects 2011 - 2016 Cycle.

DOPSAJ, M.; MARKOVIC, M.; KASUM, G.; JOVANOVIC, S.; KOROPANOVSKI, N.; VUKOVIC, M. \& MUDRIC, M. Discriminación de diferentes índices de estructura corporal de atletas de élite en deportes de combate medidos por el método de bioimpedancia de múltiples frecuencias. Int. J. Morphol., 35(1):199-207, 2017.

RESUMEN: Para obtener logros deportivos de alto nivel, es necesario conseguir el estatus adecuado dependiendo de varios factores, entre los cuales destaca el factor morfológico. El objetivo de este estudio fue definir los indicadores más discriminantes de la composición corporal o índices morfológicos, por lo cual se puedan monitorear los cambios específicos en la estructura del cuerpo en relación con la rama del deporte y el tipo de deportes de combate. Las variables del estudio fueron: altura del cuerpo, masa corporal, índice de masa corporal, índice de masa grasa, índice de proteína masa, índice de masa del músculo esquelético, porcentaje de grasa corporal, porcentaje de masa del músculo esquelético y el índice grasa proteína. La medición de la composición corporal fue realizada utilizando la bioimpedancia segmentaria multicanal con Inbod café 720 sobre una muestra de 112 deportistas de sexo masculino de categoría sénior, miembros nacionales seleccionados de la República de Serbia (62 practicantes de judo, 29 practicantes de lucha grecorromana y 21 practicantes de karate). El análisis discriminativo demostó que las submuestras de los atletas en general difieren significativamente en la morfología a nivel de lambda de Wilks - 0.435, ( $\mathrm{p}=0.000)$, y que las siguientes variables tienen la mayor discriminación en relación con la prueba de los atletas en la función del deporte: porcentaje de la masa esquelética (0.34), porcentaje de grasa corporal $(0,28)$ y el índice de grasa proteína $(0.26)$, como el primer factor aislado $(\mathrm{p}=0.000)$, lo que explica $86,3 \%$, respectivamente la masa corporal (0.74), el índice de músculo esquelético $(0,73)$, el índice de proteína de masa $(0,72)$, índice de masa corporal $(0,72)$, e índice de masa libre de grasa $(0,70)$, como el segundo factor $(\mathrm{p}=0,030)$, lo que explica $13,7 \%$ de las mediciones espaciales de variabilidad. Al definir los módulos morfológicos de los practicantes de judo, karate y lucha grecorromana para las variables investigadas y usando el método tecnológico de medida más nuevo (InBody 720), hemos obtenido nuevas informaciones que caracterizan las especificidades de los deportes, lo que contribuye a la ampliación y el desarrollo de los conocimientos anteriores sobre dicho asunto.

PALABRAS CLAVE: Artes marciales; Deportistas de élite; Estructura corporal; Bioimpedancia.

\section{REFERENCES}

Andreoli, A.; Monteleone, M.; Van Loan, M.; Promenzio, L.; Tarantino, U. $\&$ De Lorenzo, A. Effects of different sports on bone density and muscle mass in highly trained athletes. Med. Sci. Sports Exerc., 33(4):507-11, 2001.

Arslanoglu, E.; Senel, Ö. \& Aydogmus, M. Weight loss and lactic acid relation during wrestling match in elite Greco-Roman wrestlers. Int. J. Phys. Educ. Sports Health., 1(4A):1-6, 2015.

Artioli, G. G.; Gualano, B.; Franchini, E.; Scagliusi, F. B.; Takesian, M.; Fuchs, M. \& Lancha, A. H. Jr. Prevalence, magnitude, and methods of rapid weight loss among judo competitors. Med. Sci. Sports Exerc., 42(3):436-42, 2010.
Cirkovic, Z.; Jovanovic, S. \& Kasum, G. Borenja (Martial Arts). Beograd, Univerzitet u Beogradu, Fakultet Sporta i Fizickog Vaspitanja, 2010.

Clarys, P.; Geelen, B.; Aerenhouts, D.; Deriemaeker, P. \& Zinten, E. Estimation of body composition in adolescent judo athletes. J. Combat Sports Martial Arts, 2(2):73-7, 2011.

Dopsaj, M.; Blagojevic, M.; Marinkovic, B.; Miljus, D.; Vuckovic, G.; Koropanovski, N.; Ivanovic, J.; Atanasov, D. \& Jankovic, R. Model Characteristics of the Basic Anthropometric Indicators and Basic Motor Skills (BMS) at Healthy and Trained Persons of Both Sexes Population Indicators of the Republic Of Serbia. Beograd, Kriminalisticko-Policijska Akademija, 2010. 
Dopsaj, M.; Todorov, I.; Vukovic, M. \& Radovanovic, D. Various morphological indicators in elite judo athletes defined by multifrequency bioelectrical impedance analysis. Serb. J. Sports Sci., 7(3):129-41, 2013.

Franchini, E.; Nunes, A. V.; Moraes, J. M. \& Del Vecchio, F.B. Physical fitness and anthropometrical profile of the Brazilian male judo team. $J$. Physiol. Anthropol., 26(2):59-67, 2007.

Gibson, A. L.; Holmes, J. C.; Desautels, R. L.; Edmonds, L. B. \& Nuudi, L. Ability of new octapolar bioimpedance spectroscopy analyzers to predict 4-component-model percentage body fat in Hispanic, black, and white adults. Am. J. Clin. Nutr., 87(2):332-8, 2008.

Grasgruber, P.; Cacek, J.; Kalina, T. \& Sebera, M. The role of nutrition and genetics as key determinants of the positive height trend. Econ. Hum. Biol., 15:81-100, 2014.

Hair, J.; Anderson, R.; Tatham, R. \& Black, W. Multivariate Data Analysis. $5^{\text {th }}$ ed. New Jersey, Prentice - Hall, Inc., 1998.

Lee, H.; Park, J. E.; Choi, I. \& Cho, K. H. Enhanced functional and structural properties of high-density lipoproteins from runners and wrestlers compared to throwers and lifters. BMB Rep., 42(9):605-10, 2009.

InBody 720. The Precision Body Composition Analyzer, Instruction Manual, 1996-2008. Seoul, Biospace Co. Ltd., 2008.

Issurin, V. Principles and Basics of Advanced Athletic Training. Michigan, Ultimate athlete Concepts, 2008.

Janssen, I.; Heymsfield, S. B.; Wang, Z. M. \& Ross, R. Skeletal muscle mass and distribution in 468 men and women aged 18-88 yr. J. Appl. Physiol. (1985), 89(1):81-8, 2000.

Kasum, G. \& Dopsaj, M. Descriptive profile of body structure of top grecoroman style wrestlers defined with method of multichannel bioelectric impendance. SportLogia, 8(2):123-31, 2012.

Katic, R.; Blazevic, S.; Krstulovic, S. \& Mulic, R. Morphological structures of elite Karateka and their impact on technical and fighting efficiency. Coll. Antropol., 29(1):79-84, 2005.

Kim, J.; Cho, H. C.; Jung, H. S. \& Yoon, J. D. Influence of performance level on anaerobic power and body composition in elite male judoists. J. Strength Cond. Res., 25(5):1346-54, 2011.

Mirzaei, B. \& Akbarnezhad, A. A skill profile of elite Iranian Greco-roman wrestlers. World J. Sport Sci., 1(1):08-11, 2008.

Rakic, S.; Markovic, M.; Dopsaj, M.; Mladjan, D. \& Subosic, D. Initial model of men's muscle structure indicators defined by the method of multichannel bioelectrical impendance. Facta Univ. Phys. Educ. Sport, 11(1):23-33, 2013.

Sánchez-Puccini, M. B.; Argothy-Bucheli, R. E.; Meneses-Echávez, J. F.; López-Albán, C. A.; Ramírez-Vélez, R. Anthropometric and physical fitness characterization of male elite karate athletes. Int. J. Morphol., 32(3):1026-31, 2014

Sillanpää, E.; Cheng, S.; Häkkinen, K.; Finni, T.; Walker, S.; Pesola, A.; Ahtiainen, J.; Stenroth, L.; Selänne, H. \& Sipilä, S. Body composition in 18-to 88-year-old adults-comparison of multifrequency bioimpedance and dual-energy X-ray absorptiometry. Obesity (Silver Spring), 22(1):101-9, 2014.

Sterkowicz-Przybycien, K. L. Body composition and somatotype of the top of Polish male karate contestants. Biol. Sport, 27(3):195-201, 2010.

Vecchio, F. B.; Vecchio, A. H. M.; Gonçalves, A.; Franchini, E. \& Padovani, C. R. The canonical correlation between the biological markers of performance and physical fitness in high level judo athletes. Facta Univ. Phys. Educ. Sport, 9(2):121-9, 2011.

Wang, J. J.; Thornton, J. C.; Russell, M.; Burastero, S.; Heymsfield, S. \& Pierson, R. N. Jr. Asians have lower body mass index (BMI) but higher percent body fat than do whites: comparisons of anthropometric measurements. Am. J. Clin. Nutr., 60(1):23-8, 1994.

\author{
Corresponding author: \\ Milivoj Dopsaj \\ Department of Analysis and Diagnosis in Sport \\ Faculty of Sport and Physical Education \\ Blagoja Parovica 156 Str, \\ 11030 Belgrade \\ SERBIA
}

Telephone: +381113531000

Fax: $\quad+381113531001$

Email: milivoj@eunet.rs

Received:26-07-2016

Accepted:25-11-2016 